\title{
STUDY OF SULPHATE ORIGIN IN SHALLOW GROUNDWATER IN THE VICINITY OF BANTAR GEBANG-BEKASI LANDFILL USING SULPHUR-34 AND OXYGEN-18
}

\author{
E. R. Pujiindiyati and Syafalni \\ Center for the Application of Isotope and Radiation Technology - BATAN \\ Cinere Pasar Jum'at PO.Box 7002 JKSKL, Jakarta 12070, Indonesia
}

\begin{abstract}
STUDY OF SULPHATE ORIGIN IN SHALLOW GROUNDWATER IN THE VICINITY OF BANTAR GEBANG-BEKASI LANDFILL USING SULPHUR-34 AND OXYGEN-18. Bantar Gebang-Bekasi landfill-West Java has caused a social impact due to the possibility of groundwater contamination. An investigation to trace sulphate origin in shallow groundwater in surrounding of Bantar Gebang -Bekasi landfill had been done. The methods were related to Rafter for extraction of $\mathrm{CO}_{2}$ and Robinson-Kusakabe for extraction of $\mathrm{SO}_{2}$ gas. Both gases were injected to mass spectrometer for measuring of $\delta{ }^{18} \mathrm{O}\left(\mathrm{SO}_{4}{ }^{2-}\right)$ and $\delta{ }^{34} \mathrm{~S}$ $\left(\mathrm{SO}_{4}{ }^{2-}\right)$. The results showed that a mixing of sulphate from leachate water to shallow

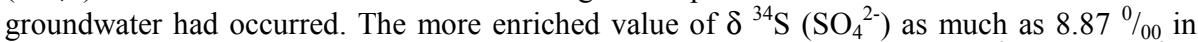
leachate water compared to shallow groundwater having that value of $3.92 \%$ to $6.66 \%$ might be caused by rapidly growth of sulphate reducing bacteria. The source of oxygen in sulphide oxidation dominantly came from atmosphere whereas percentage of $\mathrm{H}_{2} \mathrm{O}$ supplying oxygen was $0-25 \%$ for groundwater and $40 \%$ for leachate water. The extend of this value in leachate water might be caused by higher degree of bacteria, higher content of heavy metals and lower content of dissolved atmospheric oxygen.
\end{abstract}

Keywords: Landfill, Groundwater, Sulphate, Isotope

\section{INTRODUCTION}

Clean groundwater is one of the most important needs for human being. Its availability in nature is strongly related to human's activities. In recent three decades, some big cities face the problem with their quality of groundwater. There are indications that shallow groundwater and deep groundwater has deteriorated in quality. The deterioration of groundwater quality is due to several reasons such as industrial waste and urban activities as taken place in Jakarta and its vicinity. Although most sources of salinity in groundwater are natural, in some arid regions, the salinity of groundwater increases in the development of agriculture and thereby of civilization.

Municipal landfill in most regions always causes a social impact if they do not manage well as taken place in Bantar Gebang landfill. The people living in surrounding of landfill area get afraid that the groundwater might be contaminated by leachate and will not satisfy the requirements of drinking water. They also inhale highly polluted air coming from some gases released by the municipal garbage dumps. The gases such as methane, hydrogen sulphide and hydrogen are produced from the decay and dissolution of 
organic materials. Mostly, sanitary landfills contain organic materials from household waste, vegetation, wood and paper. Leachate containing high dissolved organic carbon will generate large quantities of those gases. Beside poisonous gases and high degree of bacterial activities, high contents of heavy metals such as $\mathrm{Fe}, \mathrm{Pb}, \mathrm{Hg}, \mathrm{Ag}, \mathrm{Zn}, \mathrm{Cu}$ and $\mathrm{U}$ and other chemicals such as nitrates and sulphates are also dissolved in leachate that can contaminate groundwater [1].

Water resources are not only concerned the quality of groundwater but also its sources. Natural isotopes can be used to study flow pattern, origins and chemical processes in groundwater contamination. Oxygen-18 $\left({ }^{18} \mathrm{O}\right)$ and deuterium $\left({ }^{2} \mathrm{H}\right)$ isotopes in groundwater have been applied to trace a flow pattern of leachate water in Frankfurt-Germany [2]. Previously, both isotopes have been applied in Bantar Gebang-Bekasi and showed that groundwater in the vicinities of this landfill has been contaminated by leachate water [3]. Other natural isotopes commonly applied to study of leachate water from municipal landfills are sulfur-34 and oxygen-18 in dissolved sulphates.

Sulphur enters hydrological cycle from natural and anthropogenic sources. By the year 2000, anthropogenic sulphur sources increase extremely due to much faster growth of industrial activities [2]. The importance of these anthropogenic sources of sulphur in hydrological cycle varies widely depending on the dominant sources in a given area. Similarly, the effect of isotopic composition of sulphur in any given area depends on the isotopic composition of those sources [4]. For this reason, sulphur isotope can be applied to trace the plume movement of sulphur compounds in groundwater whether it derivate from leachate water of landfill, seawater intrusion, pepticides or fertilizers in agricultural system, or sour-industrial waste. In this experiment, sulphur-34 and oxygen-18 isotopes containing in sulphate compounds $\left(\mathrm{SO}_{4}^{2}\right)$ of groundwater were used to trace the origins of sulphates in shallow groundwater in surrounding of Bantar-Gebang landfill. Oxygen-18 isotope of water $\left(\mathrm{H}_{2} \mathrm{O}\right)$ was analyzed to identify a percentage of water contribution in oxidation reaction to form sulphate compounds.

\section{EXPERIMENTAL METHODS}

Materials. The materials used in this experiment were $\mathrm{HgCl}_{2}$, liquid nitrogen, acetone p.a, $\mathrm{CO}_{2}$ gas high pure $99.9 \%$, graphite, distilled water, $\mathrm{BaCl}_{2} 10 \%$, dry ice, $\mathrm{Cl}^{-}$anion exchange resin (Dowex 50-100 mesh), $\mathrm{HCl}$ $6 \mathrm{~N}, \mathrm{NaCl} 1 \mathrm{M}, \mathrm{Cu}_{2} \mathrm{O}$ and $\mathrm{AgNO}_{3} 0.1 \mathrm{~N}$.

Equipments. The equipments used in this experiment were Sira 9 ISOGAS mass spectrometer and isoprep O-18 line, Delta S Finnigan mass spectrometer, sulphate preparation line, sulphide preparation line, analytical balance, $\mathrm{pH}$ meter, agate mortar, hot plate, platinum foil, dewar, 20-ml glass vials and 10-1t plastic bottles, glass column with diameter $28 \mathrm{~mm}$ and height $200 \mathrm{~mm}$. 
Sampling methods. For analysis of O-18 and S-34 in dissolved sulphate, the water samples were collected in 10-lt plastic bottles. As much as $1 \mathrm{mg} \mathrm{HgCl}_{2}$ was added for sulphate preservation from bacterial activities. Sampling locations of shallow groundwater, leachate water and Ciketing River in the vicinity of Bantar Gebang landfill were shown at Figure 1.

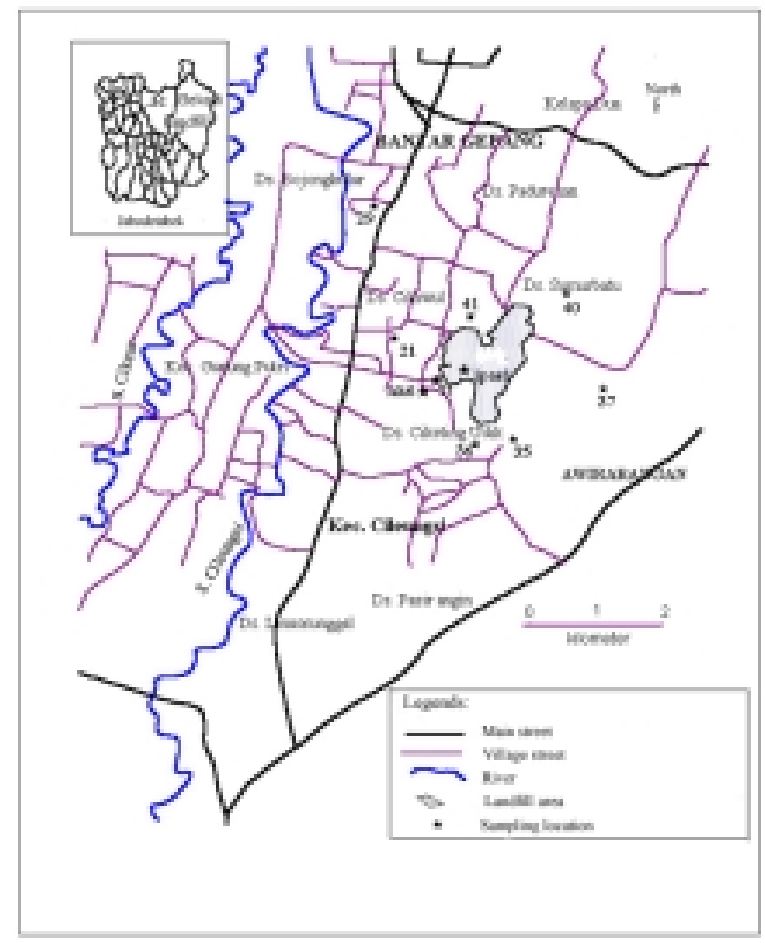

Figure 1. Sampling locations of shallow groundwater, leachate water and Ciketing River in the vicinity of Bantar Gebang landfill - Bekasi.

Preparation of $\mathrm{CO}_{2}$ gas for $\mathrm{O}-18$ isotope analysis in dissolved sulphates [5]. Water samples with low sulphate content should be passed through the ionic resin column. Ionic resin column was conditioned by eluting $150 \mathrm{ml}$ of $\mathrm{HCl}$ and $300 \mathrm{ml}$ of distilled water at a rate of $4-5 \mathrm{ml} / \mathrm{min}$. About 101 of filtered sample was passed through the column at flow rate of $150-200 \mathrm{ml} / \mathrm{min}$ such that the sulphate compound was allowed to be absorbed completely. $\mathrm{NaCl}$ of $300 \mathrm{ml}$ was eluted through column at a flow rate of $1 \mathrm{ml} / \mathrm{min}$ in order to dissolve the absorbed sulphate. A concentrated sulphate sample was reduced its $\mathrm{pH}$ to 4 by dropping $10 \% \mathrm{HCl}$ and heated $\left(90^{\circ} \mathrm{C}-100^{\circ} \mathrm{C}\right)$ to remove $\mathrm{CO}_{2}$ gas. A certain amount of $\mathrm{BaCl}_{2}$ was added to form the white precipitation of $\mathrm{BaSO}_{4}$. 
About $50 \mathrm{mg}$ precipitation of $\mathrm{BaSO}_{4}$ was grinded with graphite. This sample was transferred to platinum boat and placed to reactor in sulphate preparation line. Reduction process was taken place at the temperature of $1200^{\circ} \mathrm{C}$ under vacuum condition, its reaction as follow:

$$
\mathrm{BaSO}_{4}+3 \mathrm{C} \rightleftarrows \mathrm{BaS}+\mathrm{CO}_{2}+2 \mathrm{CO}
$$

The released water vapor was trapped using acetone-dry ice mixture whereas $\mathrm{CO}$ and $\mathrm{CO}_{2}$ gas were passed and trapped in a discharge tube which was placed in liquid nitrogen. Conversion of $\mathrm{CO}$ to $\mathrm{CO}_{2}$ gas was taken place under high voltage current $(1.2 \mathrm{KV})$, which passed through two platinum electrodes. The evolved $\mathrm{CO}_{2}$ gas was transferred to a sample bottle and ready to be injected to SIRA 9 mass spectrometer to measure ${ }^{18} \mathrm{O} /{ }^{16} \mathrm{O}$.

Preparation of $\mathrm{SO}_{2}$ gas for $\mathbf{S - 3 4}$ isotope analysis [6]. Sulphate reduction as explained above would remain in the form of $\mathrm{BaS}$ that can be precipitated as $\mathrm{Ag}_{2} \mathrm{~S}$ by adding $\mathrm{AgNO}_{3}$. About 20-30 mg of $\mathrm{Ag}_{2} \mathrm{~S}$ that have been grinded with $60-80 \mathrm{mg}$ of $\mathrm{Cu}_{2} \mathrm{O}$ were placed in platinum boat and then inserted in reactor of sulphide preparation line. This line can be loaded with six samples in one running in series. After evacuating line completely, sample was warmed at $100^{\circ} \mathrm{C}$ such that to release water vapor and other contaminating gases that could be trapped in chiller-1 kept at temperature of $-80^{\circ} \mathrm{C}$. Sample was burned at the temperature of $800-1100^{\circ} \mathrm{C}$ in 8 minutes to release $\mathrm{SO}_{2}$ gas completely. Its oxidation reaction was:

$$
\mathrm{Ag}_{2} \mathrm{~S}+3 \mathrm{Cu}_{2} \mathrm{O} \rightleftarrows 6 \mathrm{Cu}+\mathrm{SO}_{2}+\mathrm{Ag}_{2} \mathrm{O}
$$

$\mathrm{SO}_{2}$ gas was trapped at temperature of $-135^{\circ} \mathrm{C}$ in chiller-2 whereas $\mathrm{CO}_{2}$ gas will be pumped out. By heating, $\mathrm{SO}_{2}$ gas was re-evaporated and transferred to bottle dipped in liquid nitrogen. $\mathrm{SO}_{2}$ gas was injected to Delta $\mathrm{S}$ mass spectrometer to measure ${ }^{34} \mathrm{~S} /{ }^{32} \mathrm{~S}$.

Measurements of isotopic ratio value [5,7]. Isotopic ratio value was expressed with $\delta$ (delta) notation in per mill $(\%)$ and defined as follows:

$$
\delta(\% 0)=\frac{\mathrm{R}_{\text {sample }}-\mathrm{R}_{\text {reference }}}{\mathrm{R}_{\text {reference }}} \times 1000
$$

$\mathrm{R}$ is ${ }^{18} \mathrm{O} /{ }^{16} \mathrm{O}$ or ${ }^{34} \mathrm{~S} /{ }^{32} \mathrm{~S}$ expressed as $\delta{ }^{18} \mathrm{O}$ or $\delta^{34} \mathrm{~S}$. Isotopic ratio of ${ }^{18} \mathrm{O} /{ }^{16} \mathrm{O}$ in sulphates should be compared to PDB (Pee Dee Balemnitella $-\mathrm{BaCO}_{3}$ ). For data interpretation, mostly, this value was related to SMOW (Standard Mean Ocean Water) as the following equation: $\delta{ }^{18} \mathrm{O}$ sample $\left({ }^{0} \% 0\right)_{\text {SMOw }}=\delta^{18} \mathrm{O}$ sample $\left(\%{ }_{00}\right)_{\mathrm{PDB}}+1.04143$. The value of $\delta^{34} \mathrm{~S}$ related to CDT (Canon Diablo Treolite -FeS).

Measurements of sulphate content. Water samples were analyzed their sulphate content by using UV-VIS 160 Shimadzu spectrometer at the wave length of $650 \mathrm{~nm}$. 


\section{RESULTS AND DISCUSSION}

Locations, well depths and sulphate contents of shallow groundwater, leachate water and Ciketing River were presented at Table 1 whereas their isotope values of $\delta{ }^{34} \mathrm{~S}$ and $\delta{ }^{18} \mathrm{O}$ in sulphates were presented at Table 2. It was also enclosed the value of $\delta{ }^{18} \mathrm{O}$ in water from the same locations [3].

Tablel 1. Data of locations, well depth, and sulphate content of shallow groundwater, leachate water and Ciketing River in the vicinity of Bantar Gebang landfill.

\begin{tabular}{|c|c|l|c|c|}
\hline No & Sample & \multicolumn{1}{|c|}{ Location } & $\begin{array}{c}\text { Depth } \\
(\mathrm{m})\end{array}$ & $\begin{array}{c}{\left[\mathrm{SO}_{4}\right]} \\
(\mathrm{ppm})\end{array}$ \\
\hline 1 & IPAS 1 & Area TPA & - & 80.95 \\
\hline 2 & As-11 & Rumah seb. Jembatan Ciketing-Pangkalan IV & 6 & 8.64 \\
\hline 3 & As-21 & Ds. Cikiwul Rt.04/Rw06 & 15 & 3.92 \\
\hline 4 & As-29 & PT.Gayane Garment & 24 & 6.95 \\
\hline 5 & As-35 & Ds.Taman Rahayu Rt02/Rw05 & 25 & 5.75 \\
\hline 6 & As-36 & Ds. Ciketing Udik Rt02/Rw05 & 12 & 4.58 \\
\hline 7 & As-37 & Koper PU-Ds Sumur Batu & 13 & 3.64 \\
\hline 8 & As-40 & Gg. Mesjid Ds. Sumur Batu & 12 & 4.63 \\
\hline 9 & As-41 & Ds. Cikiwul Rt04/Rw04 & 12 & 6.10 \\
\hline 10 & Ak-6 & Kali Ciketing hilir (b), Utara TPA & - & 6.48 \\
\hline
\end{tabular}

Table 2. Isotopic data of $\delta{ }^{18} \mathrm{O}\left(\mathrm{SO}_{4}{ }^{2-}\right), \delta{ }^{34} \mathrm{~S}\left(\mathrm{SO}_{4}{ }^{2-}\right)$ and $\delta{ }^{18} \mathrm{O}\left(\mathrm{H}_{2} \mathrm{O}\right)$ for shallow groundwater, leachate water and Ciketing River in the vicinity of Bantar Gebang landfill.

\begin{tabular}{|c|c|c|c|c|}
\hline No & Sample & $\begin{array}{c}\delta{ }^{18} \mathrm{O}\left(\mathrm{H}_{2} \mathrm{O}\right) \\
(\%)\end{array}$ & $\begin{array}{c}\delta{ }^{18} \mathrm{O}_{(00}\left(\mathrm{SO}_{4}\right) \\
\left({ }^{\circ}{ }_{00}\right) \text { SMOW }\end{array}$ & $\begin{array}{c}{ }^{34} \mathrm{~S}\left(\mathrm{SO}_{4}\right)\left({ }^{\circ}\right) \\
\mathrm{CDT}\end{array}$ \\
\hline 1 & IPAS 1 & -3.59 & 6.46 & 8.87 \\
\hline 2 & As-11 & -6.61 & 8.80 & 5.06 \\
\hline 3 & As-21 & -6.36 & 9.29 & 4.32 \\
\hline 4 & As-29 & -5.67 & 9.30 & 6.66 \\
\hline 5 & As-35 & -6.42 & 9.79 & 6.39 \\
\hline 6 & As-36 & -6.15 & 8.26 & 4.40 \\
\hline 7 & As-37 & -7.11 & 9.31 & 3.92 \\
\hline 8 & As-40 & -6.46 & 7.02 & 4.79 \\
\hline 9 & As-41 & -5.89 & 9.29 & 11.65 \\
\hline 10 & Ak-6 & -4.87 & 5.30 & \\
\hline
\end{tabular}

\section{The source of sulphate in Bantar Gebang shallow groundwater}

In general, sulphate contents from shallow groundwater were in the range of $3.64 \mathrm{ppm}$ to $8.64 \mathrm{ppm}$ whereas leachate water taken from IPAS-1 pool had much higher sulphate content of $80.95 \mathrm{ppm}$. High sulphate content in leachate water was caused by high content of sulphur reduction states such 
as $\mathrm{H}_{2} \mathrm{~S}, \mathrm{SO}_{2}, \mathrm{~S}$ and other metal/organic sulphides that could be oxidized to sulphate. Bacterial oxidations were involved as a catalyse in sulphide oxidation [4],

$$
\begin{aligned}
& \mathrm{FeS}_{2}+3 \frac{1 / 2}{2} \mathrm{O}_{2}+\mathrm{H}_{2} \mathrm{O} \longrightarrow \mathrm{Fe}^{2+}+2 \mathrm{SO}_{4}^{2-}+2 \mathrm{H}^{+} \text {Thiobacillus thiooxidans } \\
& \mathrm{FeS}_{2}+4 \mathrm{Fe}^{3+}+8 \mathrm{H}_{2} \mathrm{O} \longrightarrow 5 \mathrm{Fe}^{2+}+2 \mathrm{SO}_{4}^{2-}+16 \mathrm{H}^{+} \text {abiological } \\
& \mathrm{Fe}^{2+}+1 / 4 \mathrm{O}_{2}+\mathrm{H}^{+} \longrightarrow \mathrm{Fe}^{3+}+1 / 2 \mathrm{H}_{2} \mathrm{O} \text { Thiobacillus ferrooxidans }
\end{aligned}
$$

The values of $\delta{ }^{34} \mathrm{~S}\left(\mathrm{SO}_{4}{ }^{2-}\right)$ from shallow groundwater were in the range from $3.92 \%$ to $6.66 \%$ whereas their $\delta{ }^{18} \mathrm{O}\left(\mathrm{SO}_{4}{ }^{2-}\right)$ values were in the range from $7.02 \%$ to $9.79 \%$. In contrast to sulphate from shallow groundwater, $\delta^{34} \mathrm{~S}\left(\mathrm{SO}_{4}{ }^{2-}\right)$ from IPAS-1 pool had much more enriched value of $8.87 \%$ and its $\delta{ }^{18} \mathrm{O}\left(\mathrm{SO}_{4}{ }^{2-}\right)$ was rather more depleted value of $6.46 \%$. The more enriched value of $\delta{ }^{34} \mathrm{~S}\left(\mathrm{SO}_{4}{ }^{2-}\right)$ and depleted value of $\delta{ }^{18} \mathrm{O}\left(\mathrm{SO}_{4}{ }^{2-}\right)$ also occurred in sulphate sample from Ciketing River that could reach $11.65 \%$ and $5.30 \%$, respectively.

Variation of isotopic composition in sulphates was dominantly caused by the degree of isotope fractionation during reduction process from sulphates to hydrogen sulphide and a part was due to isotope exchange between sulphur bearing ions, molecules or solids. Bacteria of Desulfovibrio and Desulfatomaculum controlled the reduction of sulphates by breaking $\mathrm{S}--\mathrm{O}$ bonds in which ${ }^{32} \mathrm{~S}-\mathrm{O}$ O bonds were broken more easily than ${ }^{34} \mathrm{~S}-\mathrm{-O}$ bonds [8]. As a result the first $\mathrm{H}_{2} \mathrm{~S}$ produced was enriched in ${ }^{32} \mathrm{~S}$ (or depleted in $\delta^{34} \mathrm{~S}$ ) compared to the sulphates and the residual sulphate was enriched in $\delta{ }^{34} \mathrm{~S}$. Isotopic fractionation was:

$$
{ }^{32} \mathrm{SO}_{4}(\mathrm{aq})+\mathrm{H}_{2}{ }^{34} \mathrm{~S}(\mathrm{~g}) \rightleftarrows{ }^{34} \mathrm{SO}_{4}(\mathrm{aq})+\mathrm{H}_{2}{ }^{32} \mathrm{~S}(\mathrm{~g})
$$

This reaction was controlled by either temperature or sulphate content [7].

Plotting $\delta{ }^{34} \mathrm{~S}\left(\mathrm{SO}_{4}{ }^{2-}\right)$ versus $\delta{ }^{18} \mathrm{O}\left(\mathrm{SO}_{4}{ }^{2-}\right)$ data as given at Figure 2 indicated the cluster of shallow groundwater samples lied separately with the point of leachate water and river water of Ciketing. This case could be explained that in a more stagnant water body and open system like IPAS-1 pool, the growth of sulphate reducing bacteria was much faster with decreasing of oxygen content. Under this condition, the environment became poisoned by $\mathrm{H}_{2} \mathrm{~S}$ produced continually and fractionation isotope took place with the result of enriched ${ }^{34} \mathrm{~S}$ in residual sulphates [7].

More complicated mixing of sulphate sources might occur in Ciketing

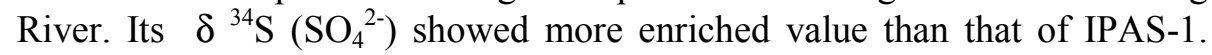
Sulphate of Ciketing River could be derived from dissolution of sulphate rock, sulphate fertilizers, industrial wastes or leachate water. But, the later was considered as a dominant sulphate source to sulphate of Ciketing River due to its sampling point which located near to landfill. 


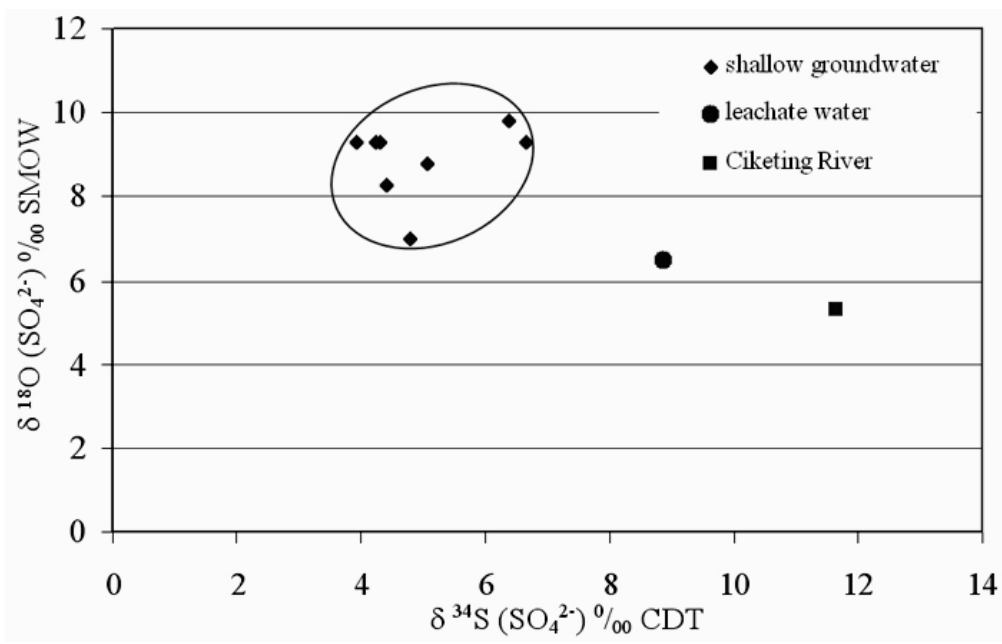

Figure 2. Variation $\delta{ }^{34} \mathrm{~S} \quad\left(\mathrm{SO}_{4}{ }^{2-}\right)$ versus $\delta{ }^{18} \mathrm{O} \quad\left(\mathrm{SO}_{4}{ }^{2-}\right)$ for shallow groundwater, leachate water and Ciketing River.

Figure 2 showed that leachate water might not solely contribute to its shallow groundwater. However, this fact needed to be observed further by plotting $\delta{ }^{34} \mathrm{~S}\left(\mathrm{SO}_{4}{ }^{2-}\right)$ values versus sulphate concentrations. Mixing process with other sulphate sources during groundwater movement also affected the isotopic composition of dissolved sulphate, which would no longer reflect that of major source such as leachate water.

The general mixing equations for two waters (source A and B) with sulphates of different isotope compositions could be approached by isotopic balance as this expression: $\mathrm{C}_{\mathrm{A}} \delta_{\mathrm{A}}+\mathrm{C}_{\mathrm{B}} \delta_{\mathrm{B}}=\mathrm{C} \delta$. A plot of $\delta$ versus concentration $^{-1}$ of sulphate (or $\mathrm{C}$ in observed site) gave a straight line with further equation as: $\delta=[$ constant $/ \mathrm{C}]+\delta_{\mathrm{B}}$, suggesting that $\mathrm{C}_{\mathrm{A}}, \delta_{\mathrm{A}}$ and $\delta_{\mathrm{B}}$ are fixed [2].

Plot of $\delta{ }^{34} \mathrm{~S}\left(\mathrm{SO}_{4}{ }^{2-}\right)$ values versus $1 /\left[\mathrm{SO}_{4}{ }^{2-}\right]$ of shallow groundwater and leachate water in Figure 3 had a straight line with equation of $\mathrm{y}=-17.14 \mathrm{x}+8.40$. Intercept of this equation was 8.40 , fixed at previous equation as $\delta_{\mathrm{B}}$ value of source B. Seemly, this line moved to $\delta{ }^{34} \mathrm{~S}_{\left(\mathrm{SO}_{4}{ }^{2-}\right)}$

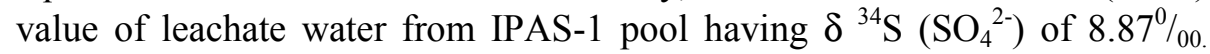
However, this case indicated that leachate water migration had contributed to sulphate of shallow groundwater in the vicinity of Bantar Gebang landfill. The indication of leachate water migration to shallow groundwater obviously supported to the result of ${ }^{18} \mathrm{O}$ and ${ }^{2} \mathrm{H}$ isotope in $\mathrm{H}_{2} \mathrm{O}$, hydrochemicals and nitrat content monitoring [3]. 


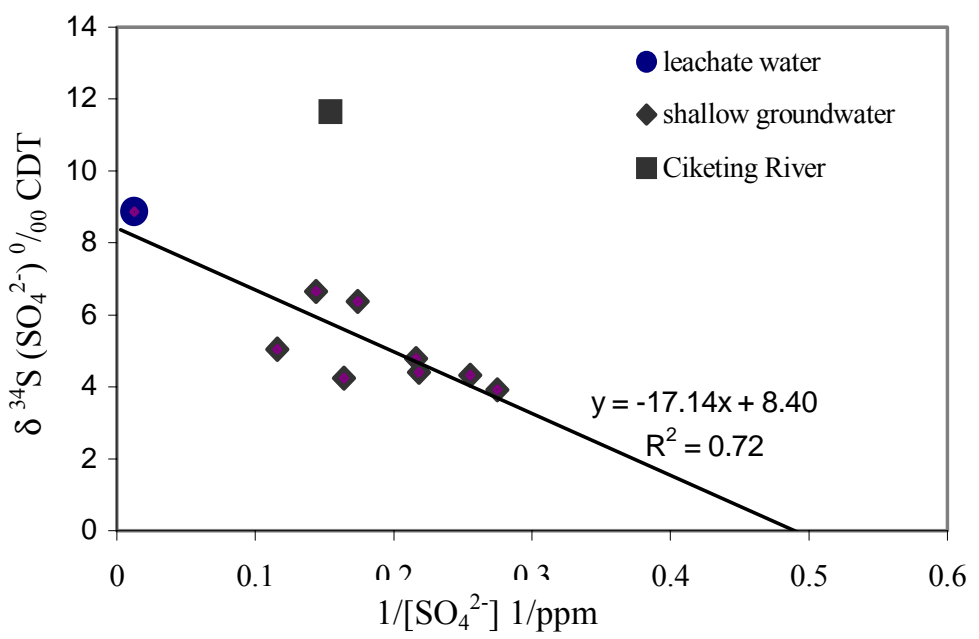

Figure 3. Relationship $\delta{ }^{34} \mathrm{~S} \quad\left(\mathrm{SO}_{4}{ }^{2}\right)$ versus sulphate concentration ${ }^{-1}$ for shallow groundwater, leachate water and Ciketing River.

\section{The source of oxygen in sulphates from Bantar Gebang shallow groundwater}

Relationship between $\delta{ }^{18} \mathrm{O}\left(\mathrm{SO}_{4}{ }^{2}\right)$ and $\delta{ }^{18} \mathrm{O}\left(\mathrm{H}_{2} \mathrm{O}\right)$ values from shallow groundwater, leachate water and river water was showed at Figure 4. The $\delta{ }^{18} \mathrm{O}\left(\mathrm{H}_{2} \mathrm{O}\right)$ value from leachate water and Ciketing River exhibited more enriched than those from shallow groundwater indicating that evaporation effect will be more extensive in open systems as taking place in IPAS-1 pool and Ciketing River. The points of shallow groundwater seem moving in quite narrow of $\delta{ }^{18} \mathrm{O}\left(\mathrm{H}_{2} \mathrm{O}\right)$ as much as $1.44 \%$ and wider range of $2.77 \%$ in $\delta{ }^{18} \mathrm{O}\left(\mathrm{SO}_{4}{ }^{2}\right)$. The vertical position of points represented reduction of some sulphate followed by oxidation of the product sulphide or subsurface oxidation of organic sulphur and metal sulphides whereas horizontal positions defined dilution of meteoric water or evaporation process [9].

Beside $\delta{ }^{18} \mathrm{O}\left(\mathrm{H}_{2} \mathrm{O}\right)$, the atmospheric oxygen having $\delta{ }^{18} \mathrm{O}\left(\mathrm{O}_{2}\right)$ value of $23 \%$ [10] could have an influence to the extent of $\delta^{18} \mathrm{O}\left(\mathrm{SO}_{4}{ }^{2}\right)$ composition. The ${ }^{18} \mathrm{O}\left(\mathrm{SO}_{4}{ }^{2}\right)$ values might be a mixture of these two end member sources. Percentage of $\mathrm{H}_{2} \mathrm{O}$ molecules involved in sulphide oxidation reaction to form dissolved sulphate was also given at Figure 4 [11]. Contribution of oxygen from $\mathrm{H}_{2} \mathrm{O}$ was in the range of $0-25 \%$ for shallow groundwater and around $40 \%$ for leachate water. 


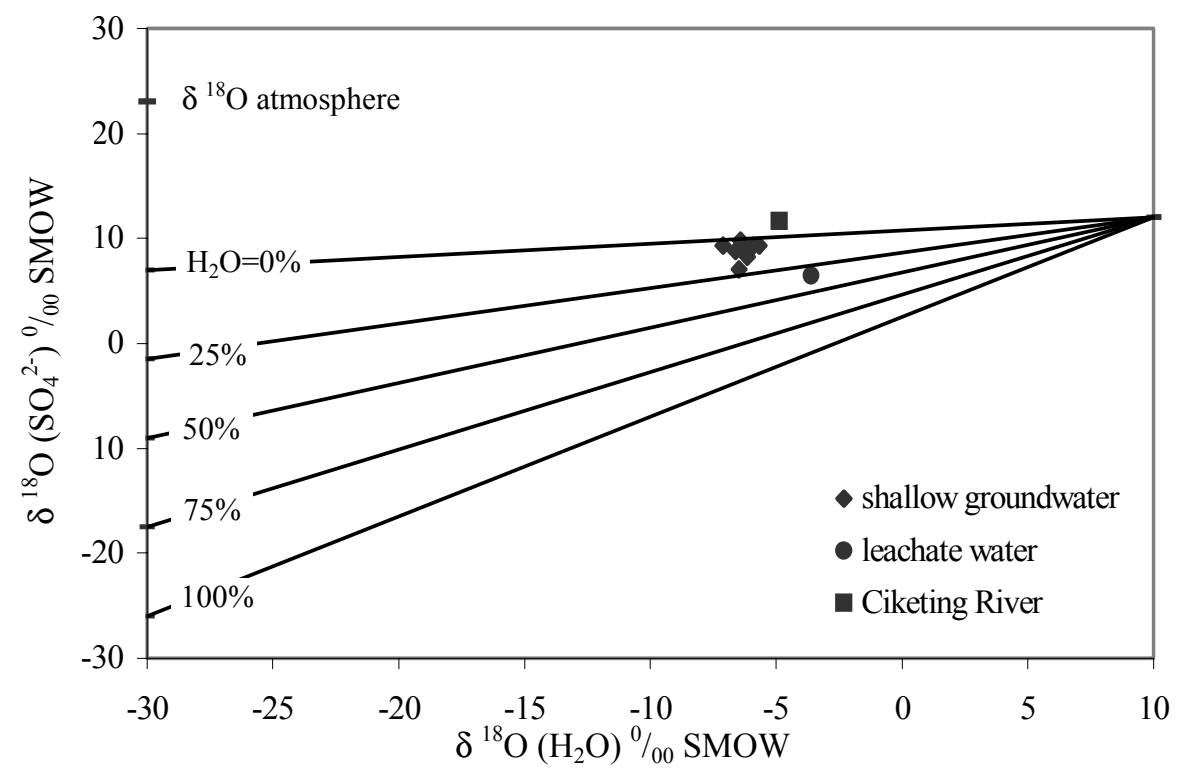

Figure 4. The oxygen isotopic composition in sulphate and water for shallow groundwater, leachate water and Ciketing River according to the percent water in the oxidation reaction.

The lower percentages of water exhibited that molecular oxygen from atmosphere more affected to $\delta{ }^{18} \mathrm{O}\left(\mathrm{SO}_{4}{ }^{2}\right)$ values either in shallow groundwater or leachate water. In the case for leachate water from IPAS-1 having higher water percentage or more depleted value of $\delta{ }^{18} \mathrm{O}\left(\mathrm{SO}_{4}{ }^{2}\right)$ reflected the high degree to which bacterial oxidation involved, increasing heavy metal contents and decreasing dissolved oxygen content from atmosphere [9]. Common case predicts the contribution oxygen from water to be $0 \%-25 \%$ for non-saturated conditions and $35 \%-100 \%$ for abiotic, saturated conditions [4]. Seemly, reaction (1) above could be an important sulphide oxidation to contribute considerable amount of sulphate in shallow groundwater, leachate water and Ciketing river. In the case reaction (2) or (3) occurred, $\delta{ }^{18} \mathrm{O}\left(\mathrm{SO}_{4}{ }^{2}\right)$ values of samples would be similar to $\delta{ }^{18} \mathrm{O}\left(\mathrm{H}_{2} \mathrm{O}\right)$ or $\delta{ }^{18} \mathrm{O}\left(\mathrm{O}_{2}\right)$.

\section{CONCLUSION}

The values of $\delta^{34} \mathrm{~S}\left(\mathrm{SO}_{4}{ }^{2-}\right)$ from shallow groundwater in the vicinity of Bantar Gebang landfill were in the range from $3.92 \%$ to $6.66 \%$ and its sulphate content were between $3.64 \mathrm{ppm}$ and $8.64 \mathrm{ppm}$. In contrast to those values, $\delta{ }^{34} \mathrm{~S}_{\left(\mathrm{SO}_{4}{ }^{2-}\right)}$ from leachate water in IPAS-1 pool was $8.87^{\circ} \%$ and its 
sulphate content was $80.95 \mathrm{ppm}$. By plotting both parameters, there was an indication that sulphate from shallow groundwater mainly came from a mixing process with sulphate from leachate water. The more enriched value of $\delta{ }^{34} \mathrm{~S}\left(\mathrm{SO}_{4}{ }^{2-}\right)$ in leachate water might be caused by rapidly growth of sulphate reducing bacteria such that the higher rate of isotopic fractionation would occur.

Shallow groundwater in the vicinity of Bantar Gebang landfill had $\delta^{18} \mathrm{O}\left(\mathrm{SO}_{4}{ }^{2-}\right)$ values from $7.02 \%$ to $9.79 \%$ whereas leachate water showed more depleted value of $6.46 \%$. Plotting between $\delta^{18} \mathrm{O}\left(\mathrm{SO}_{4}{ }^{2-}\right)$ values and $\delta^{18} \mathrm{O}\left(\mathrm{H}_{2} \mathrm{O}\right)$ as reported in previous observation gave water percentage supplying oxygen in sulphide oxidation as much $40 \%$ for leachate water and $0-25 \%$ for groundwater. It means that atmospheric oxygen dominantly contributed in sulphide oxidation reaction to form dissolved sulphate. The lower $\delta{ }^{18} \mathrm{O}\left(\mathrm{SO}_{4}{ }^{2}\right)$ value of leachate water followed by higher water percentage compared to those of shallow groundwater might be influenced by high degree to which bacterial oxidation involved like Thiobacillus thiooxidans, increasing heavy metal contents and decreasing dissolved oxygen content from atmosphere.

\section{REFERENCES}

1. M. ALI, Buletin Pengairan, Bandung, 8 (1999).

2. P. FRITZ and C.H. FONTES, "Handbook of Environmental Isotope Geochemistry", Elsevier Publishers, Amsterdam (1980).

3. SYAFALNI, "Disertasi: Kajian Teknik Hidroisotop Untuk Mempelajari Dinamika Aliran Air Tanah Dangkal Tempat Pembuangan Akhir (TPA) Bantar Gebang", Program Pascasarjana Institut Pertanian Bogor, Bogor (2002).

4. I. CLARK and P. FRITZ, "Environmental Isotopes in Hydrogeology"Lewis publishers, Boca-Ratan-New York (1997).

5. T.A. RAFTER, "Method for Extraction of Oxygen and its Quantitative Conversion of Carbon Dioxide for Isotope Radiation Measurement", New Zealand of Science, 10, 493 (1967).

6. B.W. ROBINSON and K.MINORU, Analytical Chemistry, 47, 1179 (1975).

7. J. HOEFS, "Stable Isotope Geochemistry", Springer-Verlag Berlin Heidelberg, New York (1980).

8. P. FRITZ, G.M. BASHARMAL, R.J. DRIMMIE, J. IBSEN and R.M. QURESHI, J. Chemical Geology, 79, 99 (1989). 
9. H.R. KROUSE and R.O. EVERDINGEN, Nature, 315, 663 (1985).

10. Y. HORIBE, K. HIGEHARA and Y. TAKAKUWA, J. Geophy., 78, 2265 (1973).

11. R.O. EVERDINGEN and H.R. KROUSE, Nature, 315, 345 (1985). 